\title{
Peran Perempuan dan Kearifan Lokal Indonesia dalam Media Film
}

\author{
Dwi Kartikawati \\ Universitas Nasional, Jakarta, Indonesia
}

\begin{abstract}
ABSTRAK
Riset ini memfokuskan pada pemaknaan tanda-tanda pada film Tabula Rasa yang diyakini penulis memunculkan peran perempuan dalam mempertahankan eksistensi budaya lokal Indonesia. Budaya lokal Indonesia merupakan kekayaan Indonesia yang mengandung kearifan lokal sebagai kebijakan hidup dan tata nilai atau perilaku hidup masyarakatnya. Peran perempuan tersebut digambarkan melalui media film. Walaupun tidak sederhana, namun produksi film memiliki berbagai kepentingan, setidaknya dapat menguatkan peran perempuan melalui media yang selama ini terkadang digambarkan media dengan posisi marginal. Perempuan masih sering dipandang berada di bawah laki-laki dan dianggap sebagai obyek, sehingga kekuasaan laki-laki atas perempuan sebagai kekuasaan dominan terhadap subordinat. Penelitian ini adalah penelitian kualitatif dengan metode semiotika John Fiske, yang membagi kode-kode ke dalam tiga level yaitu level relaitas, level representasi dan level ideologi. Hasil penelitian menunjukkan bahwa film Tabula Rasa memiliki tujuan dalam menguatkan peran perempuan dalam mempertahankan kearifan lokal melalui performa kekuatan diri yang dimiliki. Hasil analisis pada level realitas dan level representasi menunjukkan ciri kearifan lokal yang dimiliki pada budaya Minang yaitu pada kekuatan dalam menyajikan masakan khas daerah tersebut yang terkandung nilai nilai kekuatan diri perempuan. Pada level ideologi dapat menguatkan ideologi matrilineal yang melekat di budaya Minang. Dengan demikian penguraian kandungan makna dalam film tersebut menguatkan identitas dan peran perempuan dalam Budaya Indonesia.
\end{abstract}

\section{ABSTRACT}

This research focused on the interpretation of signs in the film titled Tabula Rasa. This film is one example of media that highlights the roles of women in preserving Indonesian local culture. Indonesian local culture is the wealth of Indonesia which contains life policies and values or behavior of the people. The role of the woman is illustrated through film media. Despite the long process of production, the creation of this film is significantly important as an art that depicts women's notable roles in the society that tends to marginalize them. Women are still below men and are considered as objects, so that men's power over women as dominant over subordinates. This research used a qualitative method utilizing the theory of semiotics by John Fiske, which divides the codes into three levels, namely the level of reality, the level of representation and the level of ideology. The results showed that this film substantially exposed and highlighted that Indonesian women possess resilience and great potential in preserving their local wisdom, on the strength in presenting regional specialties so that contained the value of women's

\section{KEYWORDS}

Roles; Women; Local Wisdom; Indonesia; Film 
self-strength. At the level of ideology, it can strengthen the matrilineal ideology inherent in Minang culture. The results of signs interpretation in this film will then strengthen women's identity and roles in Indonesian society and culture.

\section{PENDAHULUAN}

Konstruksi gender dalam masyarakat Indonesia ada dua sisi yaitu laki-laki dan perempuan. Dengan pembagian tersebut kemudian terdapat pembagian peran kerja antara laki-laki dan perempuan. Kalau kita berbicara mengenai perempuan maka tidak dapat dilepaskan dari kebudayaan. Kebudayaan dan kearifan lokal berkaitan erat dengan perempuan sebagai aktor utama. Perempuan memiliki peran besar dalam mempertahankan kebudayaan dan kearifan lokal yang melalui serangkaian proses akan membawa kemanfaatan dari masyarakat itu sendiri. Peran tersebut diwujudkan dalam aktivitas sosial seorang perempuan dalam bermasyarakat atau dalam mengaktualisasikan dirinya pada lingkungan di mana dia berada. Peran berhubungan dengan status seseorang pada kelompok tertentu atau situasi sosial tertentu yang dipengaruhi oleh seperangkat harapan orang lain terhadap perilaku yang seharusnya ditampilkan oleh orang yang bersangkutan (Ahdiah, 2013, p. 1087). Dengan demikian, peran adalah keseluruhan pola budaya yang dihubungkan dengan status individu yang bersangkutan. Maka penilaian terhadap terhadap keragaan suatu peran sudah menyangkut nilai baik dan buruk, tinggi dan rendah atau banyak dan sedikit. Peran gender yang dibebankan pada seseorang atau sekelompok orang di dalam suatu masyarakat yang ditentukan oleh keadaan mereka sebagai perempuan dan atau lelaki yang sudah mencakup aspek penilaian. Dalam melaksanakan perannya, perempuan berhadapan dengan nilai-nilai yang disematkan masyarakat kepadanya, nilai-nilai yang terkadang diskriminatif hanya karena perbedaan jenis kelamin dengan laki-laki. Ada anggapan bahwa perempuan memiliki karakter rajin berakibat para pekerja domestik rumah tangga menjadi tanggungjawab perempuan. Padahal semestinya ketika melakukan pemahaman gender adalah untuk pencapaian kesetaraan dan kesederajatan atau kesederajatan dan keadilan dalam tatanan kehidupan berkeluarga, bermasyarakat, dan bernegara (Hubeis, 2010). Namun perempuan masih sering dipandang berada di bawah laki-laki dan dianggap sebagai obyek, sehingga kekuasaan laki-laki atas perempuan sebagai kekuasaan dominan terhadap subordinat

Nilai-nilai lokal dan pengetahuan lokal yang telah lama tertanam pada masyarakat dapat senantiasa terpelihara dan berkembang menjadi modal yang tak ternilai dalam pembangunan, disinilah terkandung kearifan lokal. Dalam Kamus Inggris Indonesia local berarti setempat. Indonesia adalah negara kepulauan terbesar di dunia. Indonesia memiliki lebih dari 17.000 pulau, dan hanya sekitar 7.000 pulau yang berpenghuni (Konsulat Jendral Republik Indonesia: Frankfurt, 2016). Kalimantan, Jawa, Sulawesi, Sumatra dan Papua merupakan pulau utama di Indonesia. Selain itu Indonesia juga memiliki pulau-pulau kecil seperti Bali, Karimunjawa, Gili dan Lombok yang merupakan 
tujuan wisata lokal maupun internasional. Ibukota negara Indonesia adalah Jakarta, yang terletak di Pulau Jawa. Indonesia memiliki keberagaman yang merupakan kekayaan dan keindahan bangsa Indonesia.

Sedangkan wisdom (kearifan) sama dengan kebijaksanaan. Secara umum maka local wisdom (kearifan setempat) dapat dipahami sebagai narasi kehidupan milik bersama suatu entitas sekaligus sebagai pedoman yang dapat menuntun manusia dalam berperilaku dan bertindak (Nesi et al., 2019, p. 71). Kearifan lokal adalah cara orang bersikap dan bertindak dalam merespon lingkungan fisik dan budaya. Kearifan lokal atau local wisdom dapat dipahami sebagai gagasan-gagasan setempat local yang bersifat bijaksana, penuh kearifan, bernilai baik, yang tertanam dan diikuti oleh anggota masyarakatnya (Istiawati, 2016, p. 5). Lebih jauh menurut Fajarini (2014, p. 123), kearifan lokal adalah pandangan hidup dan ilmu pengetahuan serta berbagai strategi kehidupan yang berwujud aktivitas yang dilakukan oleh masyarakat lokal dalam menjawab berbagai masalah dalam pemenuhan kebutuhan. Dalam bahasa asing sering juga dikonsepsikan sebagai kebijakan setempat "local wisdom" atau pengetahuan setempat "local knowledge" atau kecerdasan setempat "local genious."

Kearifan lokal Indonesia merupakan pengetahuan yang dimiliki oleh sekelompok orang yang hidup di wilayah tertentu. Kearifan lokal yang demikian telah menyatu dengan sistem kepercayaan, norma dan budaya dan diekspresikan di dalam tradisi dan mitos, yang dianut dalam waktu yang cukup lama. Kearifan lokal perlu dipahami sebagai basis sosial yang memiliki kekuatan penggerak untuk pengembangan masyarakat. Upaya penggambaran kearifan lokal dapat kita lihat melalui media khususnya media film. Film secara umum dapat dibagi atas dua unsur pembentuk, yaitu unsur naratif (cerita) dan unsur sinematik. Dua unsur tersebut saling berinteraksi dan berkesinambungan satu sama lain untuk membentuk sebuah film. (Pratista, 2008, p. 1) Dalam hal ini, yang dimaksud unsur naratif adalah aspek-aspek ceritanya. Sementara unsur sinematik adalah aspek-aspek teknisnya, seperti kostum, make-up, atau tata cahaya. Kedua unsur tersebut harus dapat berjalan seimbang agar dapat menghasilkan film yang bagus dan menarik.

Kekuatan dan kemampuan film menjangkau banyak segmen di masyarakat, mengakibatkan film berpotensi untuk mempengaruhi khalayaknya. Film yang merupakan karya sinematografi dapat berfungsi sebagai alat cultural education atau pendidikan budaya. Film dapat berfungsi sebagai cerminan kebudayaan suatu bangsa dan memengaruhi budaya itu sendiri. Namun film yang bagus dan berkualitas tidak hanya dilihat dari alur ceritanya saja. Sebuah film seharusnya mampu memenuhi tiga misi perfilman itu sendiri dan juga sesuai dengan fungsi film, yaitu sebagai media hiburan, edukasi dan informasi juga sebagai culture education yaitu dengan mengandung unsur kearifan lokal. Bahkan Undang-Undang Film Tahun 2009 Indonesia menyebut film sebagai “...karya seni budaya memiliki peran strategis dalam peningkatan ketahanan budaya bangsa dan kesejahteraan masyarakat lahir batin untuk memperkuat ketahanan nasional" dan "film sebagai media komunikasi massa merupakan sarana pencerdasan 
kehidupan bangsa, pengembangan potensi diri, pembinaan akhlak mulia, pemajuan kesejahteraan masyarakat, serta wahana promosi Indonesia di dunia internasional" (Suryani, 2014, p. 80). Media film memiliki kekuatan dan juga peran besar dalam membentuk realitas. Realitas adalah hasil cipta atau kontruksi social invidu yang merupakan cipta kreasi dari manusia melalui kekuatan kontruksi social pada dunia social yang ada.

Salah satu film di Indonesia yang mengandung kearifan lokal adalah Film Tabula Rasa. Film Tabula Rasa menjadi film peraih empat Piala Citra Festival Film Indonesia sejak dirilis 2014. Tabula Rasa mendapatkan banyak penghargaan dalam Penghargaan Piala Citra di FFI (Festival Film Indonesia) 2014 sebagai pemenang sutradara terbaik Adriyanto Dewo, pemeran utama wanita terbaik Dewi Irawan, pemeran pendukung pria terbaik Yayu Unru, dan penulis skenario asli terbaik Tumpal Tampubolon. Film berdurasi 107 menit ini pernah meraih piala citra pada kategori Sutradara Terbaik (Adriyanto Dewo), Skenario Asli Terbaik (Tumpal Tampubolon), Pemeran Utama Wanita Terbaik (Dewi Irawan sebagai Mak), dan Pemeran Pendukung Pria Terbaik (Yayu Unru sebagai Parmanto). Apabila dilihat dari genre film (tema cerita), Film Tabula Rasa merupakan jenis film drama yaitu film yang menekankan pada sisi kemunusiaan atau human interest yang tujuannya adalah untuk mengajak penonton ikut merasakan kejadian yang terjadi dalam cerita film tersbeut sehingga para penonton merasa seakan-akan berada di dalam film tersebut. Tidak jarang penonton akan ikut merasakan sedih, senang, kecewa bahkan ikut marah dan lain-lain.

Pada tahun 2018 film ini diputar kembali di dalam segmen khusus Festival Film Internasional Sofia (SIFF) Bulgaria yang berlangsung pada 7-29 Maret 2018 di beberapa bioskop di Bulgaria. Tabula Rasa jadi film Indonesia pertama yang berpartisipasi dalam SIFF, yang merupakan festival film terbesar di Bulgaria dan juga merupakan salah satu festival bergengsi di Eropa. Penonton sekitar 80 ribu orang menyaksikan berbagai film internasional yang diputar dalam SIFF. Pemutaran film Tabula Rasa merupakan permintaan khusus dari panitia SIFF setelah dua film Indonesia lainnya yang didaftarkan tidak lolos seleksi untuk kategori kompetisi.

Tabula Rasa merupakan film yang bercerita tentang keragaman manusia Indonesia, sebuah potongan keseharian dari perjuangan yang dialami oleh banyak perantau di kota besar. Keragaman budaya dalam filmnya juga ditampilkan melalui musik. Film Tabula Rasa bercerita tentang Hans, seorang pemuda Serui, Papua yang kehilangan mimpinya untuk menjadi pemain sepak bola profesional. Hans lalu bertemu dengan Mak, pemilik sebuah rumah makan Padang yang akhirnya menuntun Hans untuk membangun kembali hidupnya melalui makanan.

Tabula Rasa merupakan film pertama di Indonesia yang mengangkat kuliner dan menjadikannya sebagai food film Indonesia. Di tengah derasnya arus investasi asing di bidang kuliner yang merambah ke negeri Indonesia (seperti Kentucky Fried Chicken, Mc 
Donald, dan Pizza Hut), kita bisa menyaksikan film Tabula Rasa yang menyajikan kuliner lokal. Tabula Rasa sendiri disutradarai oleh Adriyanto Dewo dimana ini adalah debut film panjang pertamanya. Selain itu, nama besar yang menggusung film ini adalah Sheila Timothy yang menjadi produser film ini dan sebelumnya telah mencetak film Pintu Terlarang (2009) dan Modus Anomali (2012). Kali pertama Sheila Timothy membuat film bernuansa drama dimana sebelumnya dua filmnya bernuansa Thriller yang dikemas oleh Joko Anwar. Dua film Thriller yang dibuat olehnya berhasil mengusung nama di kancah festival film internasional sudah barang tentu untuk filmnya kali ini ekspekstasi sangat besar dan taruhan besar untuk dia selaku produser yang out of the genre dari film-film sebelumnya. Nama Tabula Rasa dengan fokus cerita ke arah kuliner , mengingatkan pada Filosofi Locke, bahwa Tabula Rasa adalah teori tentang pikiran manusia yang ketika lahir berupa kertas kosong dalam artian bahwa pikiran individu 'kosong' saat lahir, dan juga ditekankan tentang kebebasan individu untuk mengisi jiwanya sendiri. Setiap individu dikatakan bebas mendefinisikan isi dari karakternya. Film Tabula Rasa yang diyakini penulis memunculkan peran perempuan dalam mempertahankan eksistensi budaya lokal dengan dilandasi nilai-nilai kearifan lokal Indonesia. Walaupun tidak sederhana, namun produksi film memiliki berbagai kepentingan, setidaknya dapat menguatkan peran perempuan melalui media yang selama ini terkadang digambarkan media dengan posisi marginal. Perempuan memiliki performa kekuatan diri yang kuat sebenarnya.

Pada penelusuran riset-riset terdahulu, dapat di lihat pada penelitian Lukitasari (2019) dari Politeknik International Bali, Tahun 2019, mengenai Penguatan Reputasi Masakan Padang: Simbol Promosi Pariwisata Gastronomi Dalam Film Tabula Rasa, menyimpulkan bahwa Film ini dapat membantu menguatkan reputasi masakan Padang sebagai salah satu daya tarik pariwisata gastronomi Indonesia. Kemudian dalam konteks penelitian semiotika lainnya, kita dapat telusuri dari penelitian Pah \& Darmastuti, yang menggunakan semiotika John Fiske melalui tiga level (level realitas, level representatif dan level ideologi) untuk menemukan makna yang tersirat dari episode pada tayangan Lentera Indonesia (Pah \& Darmastuti, 2019). Kemudian judul penelitian yaitu Multikulturalisme Cita Rasa Masakan Dalam Film “Tabula Rasa”(analisa Semiotika Charles Sanders Peirce), dari Silvana Suci Pratami, Skripsi, Universitas Mercubuana, Tahun 2015, yang juga meneliti semiotika dengan hasil penelitian menegaskan bahwa terdapat makna multikulturalisme dalam Film Tabula rasa. Ketiga penelitian tersebut menggunakan semiotika tetapi sangat berbeda dengan tujuan penulis dalam penelitian ini karena penulis menekankan pada peran perempuan dalam menguatkan identitas dan budaya Indonesia. Hal tersebut dipahami karena budaya lokal memiliki kekuatan penggerak untuk pengembangan masyarakat yang penggambaran budaya lokal dilakukan melalui media film yang sekaligus dapat memberikan pendidikan budaya bagi Bangsa Indonesia.

Dengan demikian dalam penelitian ini diharapkan dapat berkontribusi pada penelitian semiotika pada umumnya, yang mengkhususkan pada penguraian kandungan makna dalam film Tabula Rasa yang menguatkan identitas dan posisi perempuan dalam Budaya 
Indonesia. Maka permasalahan yang diangkat adalah "Bagaimana gambaran peran perempuan dalam kearifan lokal pada Film Tabula Rasa ?".

\section{METODOLOGI PENELITIAN}

Dalam penelitian ini menggunakan pendekatan kualitatif dengan metode analisis isi kualitatif yaitu analisis semiotika. Menurut Bungin (2007), penggunaan analisis isi lebih banyak ditekankan pada bagaimana simbol-simbol yang ada pada komunikasi itu terbaca dalam interaksi sosial dan bagaimana simbol-simbol itu terbaca dan dianalisis oleh penulis. Analisis isi memerlukan penulis yang mampu menggunakan ketajaman analisisnya untuk merajut fenomena isi komunikasi. Disadari bahwa makna simbol dan interaksi amat majemuk sehingga penafsiran gejala terhadap objek simbol tunggal umumnya menjadi fenomena umum dalam penelitian sosial. Oleh karena itu, analisis isi menjadi tantangan sangat besar bagi penulis itu sendiri. Oleh sebab itu, pemahaman dasar terhadap kultur dimana komunikasi itu terjadi sangat penting. Kultur ini menjadi muara yang luas terhadap berbagai macam bentuk komunikasi di masyarakat. Dalam penelitian ini penulis melakukan penguraian kandungan makna isi komunikasi dalam bentuk teks dalam film Tabula Rasa melalui narasi-narasi yang terkandung di dalamnya yang menyiratkan simbol-simbol yang menguatkan identitas dan posisi perempuan dalam Budaya Indonesia, yaitu dengan metode semiotika.

Gambar 1: Analisis isi

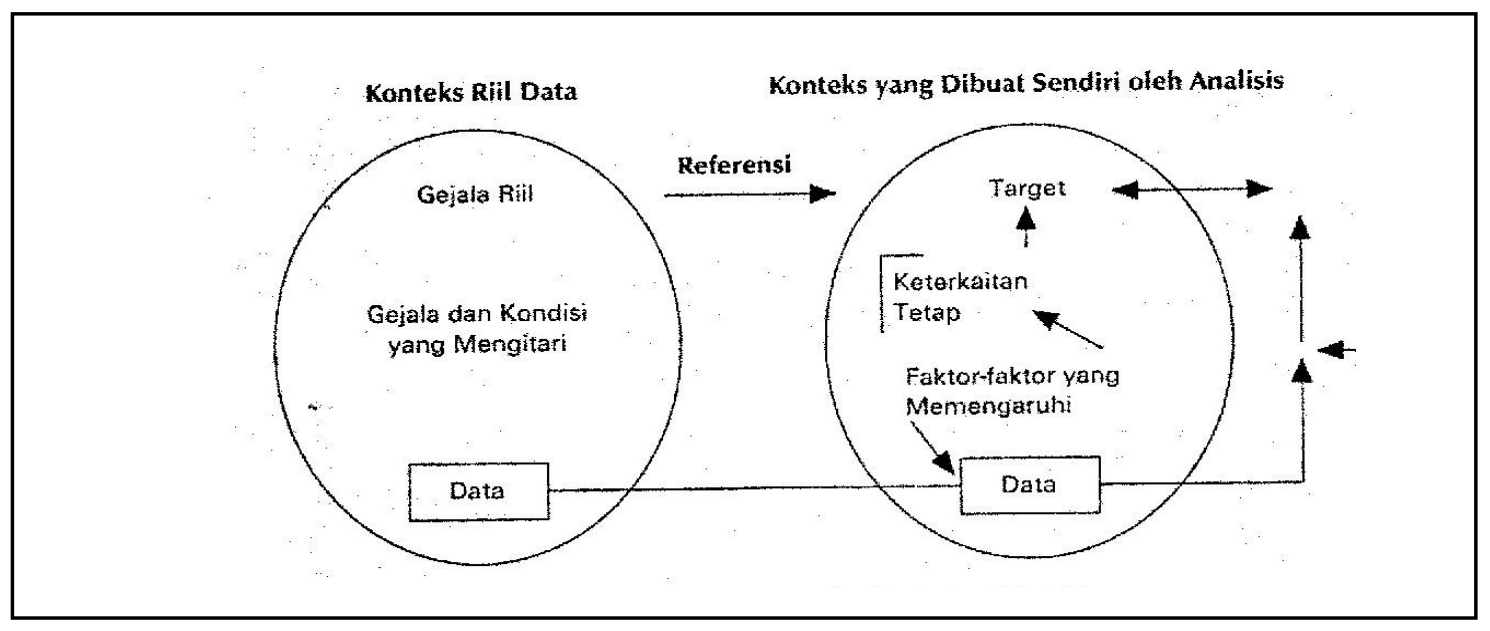

Sumber: Bungin (2007, p. 158)

Maka dalam pengumpulan data yang diperoleh dari teks film sebagai data primer, dilakukan dengan cara menggali makna peran perempuan dalam kearifan lokal berdasarkan teks yang terkandung dalam Film Tabula Rasa tersebut. Dalam analisis isi kualitatif ini, peneliti memulai analisisnya dengan menggunakan lambang-lambang tertentu, mengklasifikasi data tersebut dengan kriteria-kriteria tertentu serta melakukan prediksi dengan teknik analisis yang tertentu pula. Kemudian menggunakan analisis 
semiotika John Fiske yang membagi dalam tiga kategori yaitu level realitas, level representasi dan level ideologi.

Gambar 2. Sumber: Teknik content analysis

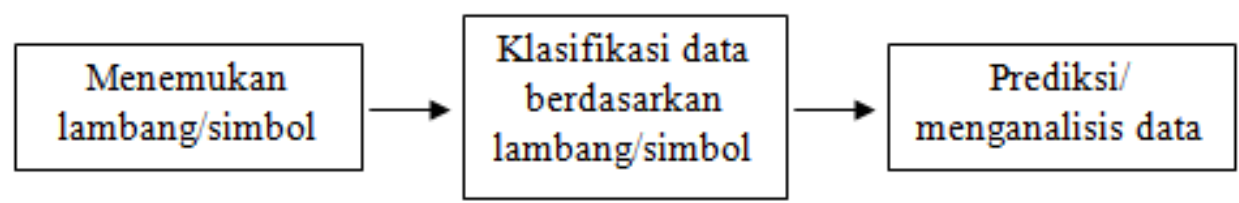

Sumber: Bungin (2007, p. 159)

Secara etimologis, istilah semiotik berasal dari kata Yunani semeion yang berarti tanda. Tanda itu sendiri didefinisikan sebagai yang atas dasar konvensi social yang terbangun sebelumnya-dapat dianggal mewakili suatu yang lain (Wibowo, 2013). Menurut Fiske, kode-kode yang muncul atau yang digunakan dalam acara televisi saling berhubungan sehingga terbentuk sebuah makna (Vera, 2014, p. 35-36). Sebuah realitas tidak akan muncul begitu saja melalui kode-kode yang timbul, namun juga diolah melalui alat indera sesuai referensi yang telah dimiliki oleh penonton televisi, sehingga sebuah kode diapresiasi secara berbeda oleh orang yang berbeda. Maka dari itu setiap orang bisa secara berbeda menanggapi sebuah makna dalam televisi, sesuai dengan latar belakang, budaya, kelas sosial, dan lain-lain. Fiske mengungkapkan bahwa peristiwa yang ditayangkan dalam dunia televisi telah di-encode oleh kode-kode sosial yang terbagi dalam tiga level berikut (Vera, 2014). Tiga level pengkodean tersebut adalah level tanda itu sendiri. Kemudian kode-kode atau sostem yang dibangun untuk mempertemukan dengan kebutuhan masyarakat dalam sebuah kebudayaan. Level Ketiga adalah Kebudayaan di mana kode dan lambang beroperasi.

Secara lebih rinci, menurut Vera (2014, p. 36), tiga level pengkodean tayangan televisi, yang dapat berlaku juga dalam film yaitu: Level Realitas itu menunjuk pada peristiwa yang ditandakan (encode) sebagai realitas. Kode yang dalam level ini adalah: tampilan, pakaian, perilaku, percakapan, gestur, ekspresi, suara, dan dalam bahasa tertulis berupa dokumen, transkrip wawancara, dan lain sebagainya. Pada Aspek realitas mencakup: (a) Pakaian. Setiap bentuk dan jenis pakaian apapun yang dikenakan oleh seseorang akan menyampaikan penanda sosial (social sign) tentang si pemakai. Pakaian mencerminkan peran seseorang, kelompok asalnya, status orang tersebut di dalam kelompok atau identitas kelompok yang membedakan dengan kelompok lainnya, status orang tersebut di dalam masyarakat yang lebih luas, hierarki, gender, memiliki nilai simbolik, dan merupakan ekspresi cara hidup tertentu. Pakaian merupakan suatu cara yang digunakan individu untuk membedakan dirinya sendiri sebagai individu dan menyatakan beberapa bentuk keunikan. Fashion atau pakaian menjadi medium yang digunakan seseorang untuk menyatakan sesuatu pada orang lain (Budiono, Herieningsih, \& Lukmantoro, 2014), (b) Penampilan (appearance). Penampilan fisik Setiap orang punya persepsi mengenai penampilan fisik. Seringkali orang memberi makna tertentu pada karakteristik fisik orang yang bersangkutan, seperti bentuk tubuh, warna kulit, model rambut, dan 
sebagainya. (c) Perilaku (behavior). Perilaku atau behavior merupakan sebuah tindakan seseorang. (d) Ekspresi (expression). Banyak orang beranggapan bahwa perilaku nonverbal yang paling banyak "berbicara" adalah ekspresi wajah, khususnya pandangan mata, meskipun mulut tidak berbicara. (e) Latar (setting). (f) Dialog (dialogue). Merupakan percakapan-percakapan antar pemeran dalam sebuah film.

Level representasi menunjuk pada realitas yang telah terkode dalam encoded electronically harus ditampakkan pada technical code, seperti kamera, lighting, penyuntingan, music, suara dan lainnya. Elemen-elemen tersebut kemudian ditransmisikan mentransmisikan kode-kode representasional yang dapat mengaktualisasikan, antara lain karakter, narasi, action, dialog, setting dan sebagainya. Kode yang tercakup dalam level ini adalah kamera, lighting, editing, musik, suara. Dimana level ini mentransmisikan kode-kode representasional yang dapat mengaktualisasikan, antara lain karakter, narasi, action, dialog, setting dan sebagainya.

Level ideologi menunjuk pada semua elemen diorganisasikan dan dikategorikan dalam kode-kode ideologis, seperti patriakhi, individualism, ras, kelas, matrealisme, kapitalisme, dan sebagainya.

Tabel 1. Kerangka kerja analisis semiotika John Fiske

\begin{tabular}{|l|l|}
\hline \multicolumn{1}{|c|}{ Level } & \multicolumn{1}{c|}{ Cakupan } \\
\hline Realitas & $\begin{array}{l}\text { Tampilan, pakaian, perilaku, percakapan, gestur, } \\
\text { ekspresi, suara,dan lain-lain }\end{array}$ \\
\hline Representasi & $\begin{array}{l}\text { Kamera, lighting, penyuntingan, music, dialog, dan } \\
\text { lain-lain }\end{array}$ \\
\hline Ideologi & Kode-kode ideologis \\
\hline
\end{tabular}

Sumber: Hasil olahan Penulis

\section{HASIL DAN PEMBAHASAN}

\section{Sinopsis Film Tabula Rasa}

Cerita Film ini diawali dengan prolog kehidupan Hans di kampung halamannya, Serui. Hans hidup di panti bersama dengan anak-anak lain dan seorang wanita yang menjadi mama baginya. Hans suka dengan bola dan bermimpi menjadi pemain bola hebat. Hingga akhirnya pada suatu hari, datang orang dari Jakarta yang melihat kemampuan hebatnya bermain bola. Hans pun diundang untuk ke Jakarta dengan orang tersebut. Disini terjadi perdebatan kecil antara mama pantinya dengan Hans. Mama panti Hans tak rela meninggalkan Hans berjuang di tengah kejamnya kehidupan ibukota. Dan Hans pun tetap memilih untuk berangkat mengejar mimpinya. Kehidupan Hans di ibukota tak sesuai dengan harapannya. Kakinya cedera dan klub bola yang menaunginya tak mampu untuk membayar biaya pengobatan. Hingga akhirnya Hans dibuang oleh klubnya, dan menjadi 
gelandangan yang bekerja serabutan untuk membeli makanan setiap hari. Kehidupannya yang begitu susah membuat dia berpikir untuk bunuh diri dengan melompat dari atas jembatan yang dibawahnya ada perlintasan kereta. Namun ternyata Hans tidak jadi melompat bunuh diri dan jatuh kebelakang. Pada paginya, Hans ditemukan tergeletak oleh seorang ibu. Ibu itupun menolong dan memberinya gulai kepala ikan. Ceritapun berlanjut dengan ibu yang ternyata pemilik rumah makan Padang itu yang ingin membantu Hans. Namun terjadi konflik besar antara sang Ibu dan Uda Parmanto. Uda tidak mau Hans ikut mereka, apalagi semenjak Hans memint balasan jasa berupa uang untuk pekerjaan yang dilakukannya di rumah makan Padang tersebut. Bagi Uda, datangnya Hans akan memperkecil bagian pendapatan yang akan diterima oleh Uni atau Mak, Uda dan Natsir. Akhirnya, puncak dari konflik antara Uda dan Uni adalah dengan keluarnya Uda dari rumah makan Takana Juo milik Uni. Uda berpindah menjadi juru masak restoran Caniago yang berada di seberang jalan di depan rumah makan Takana Juo milik Uni. Dan ternyata restoran Caniago lebih ramai daripada rumah makan Takana Juo. Uni dan Natsir pun berpikir keras bagaimana cara bertahan hidup dari persaingan dengan restoran Caniago yang tampak lebih besar dan mewah. Hans pun mengusulkan ke Uni untuk mengajarkan resep masakan Gulai Kepala Ikan yang tidak dijual di restoran Caniago. Namun Mak bergeming, masakan Gulai Kepala Ikan mempunya arti tersendiri bagi Uni atau Mak. Masakan itu hanya dimasak ketika peringatan tanggal lahir anaknya yang meninggal karena Gempa Padang silam.

Kondisi rumah makan Takana Juo yang sedang sepi dan terancam bangkrut, membuat Uni mengubah pikiran. Ia akhirnya mau untuk mengajarkan Hans cara memasak Gulai Kepala Ikan yang nantinya akan menjadi menu andalan di rumah makan Takana Juo. Berangsur-angsur rumah makan Takana Juo pun kembali ramai. Menu Gulai Kepala Ikan sukses menarik pelanggan untuk makan di Takana Juo. Di lain tempat restoran Chaniago mulai sepi pelanggan, Uda Parmanto sebagai juru masaknya merasa heran. Ia akhirnya mencari tahu apa yang menyebabkan Takana Juo kembali ramai dengan mencoba menu andalan gulai kepala ikan. Dan masakan inilah yang menyadarkan Uda Parmanto akan sikapnya selama ini pada Uni, Hans dan Natsir. Cerita kembali memuncak ketika Uni jatuh sakit dan harus dilarikan oleh Natsir ke rumah sakit. Padahal saat itu Takana Juo sedang menerima pesanan besar dari suatu pesta pernikahan. Kebingungan, akhirnya Hans meminta tolong pada Uda Parmanto untuk membantunya memasak pesanan besar tersebut. Uda Parmanto, Hans, dan Natsir pun akhirnya bahu membahu saling membantu untuk memasak bersama memenuhi pesanan. Setelah pesanan akhirnya diselesaikan, Hans bertanya kepada Uda untuk kembali ke rumah makan Takana Juo. Namun Uda menolak, baginya satu kapal hanya ada satu nahkoda. Setelah Mak kembali dari rumah sakit, Hans menceritakan semua yang dialami ketika Mak masih di rumah sakit. Akhir dari cerita ini adalah Hans keluar dari Takana Juo. 
Analisis Semiotika John Fiske pada level 1 yaitu level realitas dan level 2 yaitu representasi

\section{Peran perempuan sebagai Ibu}

Tabel 2. Analisis Pada Temuan Kategori 1

\begin{tabular}{|c|c|c|}
\hline Gambar sebagai lambang & Level realitas & Level representasi \\
\hline \multicolumn{3}{|c|}{$\begin{array}{c}\text { Kearifan Lokal: nilai integritas dalam mempertahankan Kuliner Budaya } \\
\text { Minang } \\
\text { (Masakan Gulai Kepala Ikan) }\end{array}$} \\
\hline $\begin{array}{l}\text { Mamak menganggap kalau } \\
\text { masalk ikan adalah masakan } \\
\text { untuk anaknya, sehingga } \\
\text { menganggap ketika memasak } \\
\text { gulai kepala ikan berarti dia } \\
\text { ziarah. }\end{array}$ & $\begin{array}{l}\text { Penampilan makanan } \\
\text { yang di masak tokoh } \\
\text { utama perempuan } \\
\text { yaitu Mak yang terlihat } \\
\text { mempu menampilkan } \\
\text { sosok ibu yang } \\
\text { mengurusi domestik } \\
\text { yaitu makanan. } \\
\text { Latar scene ini adalah } \\
\text { meja di dapur untuk } \\
\text { menyajikan masakan } \\
\text { yang sudah siap saji. }\end{array}$ & $\begin{array}{l}\text { Pengambilan gambar } \\
\text { close up. } \\
\text { Perempuan yang } \\
\text { memiliki integritas yaitu } \\
\text { tetap menjaga kekayaan } \\
\text { budaya kuliner masakan. } \\
\text { Musik yang mengiringi } \\
\text { menggunakan lirik lagu } \\
\text { dengan bahasa Minang. } \\
\text { Teknik pencahayaan } \\
\text { Pencahayaan utama yang } \\
\text { diarahkan pada objek. }\end{array}$ \\
\hline \multicolumn{3}{|c|}{$\begin{array}{c}\text { Kearifan Lokal: Nilai integritas dalam mempertahankan Kuliner Budaya } \\
\text { Minang } \\
\text { (Masakan Rendang, Dendeng bakar Batokok Lado Mudo) }\end{array}$} \\
\hline $\begin{array}{l}\text { Sajian makanan Minang di } \\
\text { Warung Takana Juo milik Mak si } \\
\text { tokoh utama dalam film ini. }\end{array}$ & $\begin{array}{l}\text { Penampilan makanan } \\
\text { yang di masak tokoh } \\
\text { utama perempuan } \\
\text { yaitu Mak. } \\
\text { Latar scene ini adalah } \\
\text { meja rumah makan di } \\
\text { Warung Takana Juo }\end{array}$ & $\begin{array}{l}\text { Pengambilan gambar } \\
\text { close up, } \\
\text { Perempuan yang tetap } \\
\text { menjaga kekayaan } \\
\text { budaya kuliner masakan. } \\
\text { Teknik pencahayaan } \\
\text { (membantu mengurangi } \\
\text { bayang yang dihasilkan } \\
\text { oleh key light (sumber } \\
\text { cahaya utama) sehingga } \\
\text { gambar nampak lebih } \\
\text { natural. }\end{array}$ \\
\hline
\end{tabular}




\begin{tabular}{|c|c|c|}
\hline $\begin{array}{l}\text { Iak mengajarkan } \\
\text { hembuat rendang, dendeng } \\
\text { do mudo, dan beberapa } \\
\text { lasakan daerah Sumatera } \\
\text { arat, dan Mak memberi tahu } \\
\text { lengenai daun ruku-ruku dari } \\
\text { umatera Barat kepada Hans, } \\
\text { lu saat Hans menyerap } \\
\text { eberapa kosa kata bahasa } \\
\text { linang hasil dari ia bergaul } \\
\text { engan orang Minang. }\end{array}$ & $\begin{array}{l}\text { Perilaku mengajarkan } \\
\text { memasak, percakapan } \\
\text { ketika Mak } \\
\text { mengajarkan bahasa } \\
\text { Minang kepada Hans } \\
\text { waktu mengajarkan } \\
\text { memasak, ekspesi } \\
\text { senang yang } \\
\text { ditunjukkan dari raut } \\
\text { wajah Mak } \\
\text { Latar scene ini adalah } \\
\text { dapur yang gelap dan } \\
\text { tradisional. }\end{array}$ & $\begin{array}{l}\text { Pengambilan gambar } \\
\text { medium shoot } \\
\text { Perempuan } \\
\text { memberikan } \\
\text { pembelajaran kepada } \\
\text { Hans anak yang berasal } \\
\text { dari Papua yaitu } \\
\text { mengajarkan memasak } \\
\text { rendang, Mak tetap } \\
\text { terlihat ibaratnya seperti } \\
\text { seorang ibu yang penuh } \\
\text { kasih sayang dan } \\
\text { bersedia berbagi ilmu } \\
\text { memasak masakan } \\
\text { Minang. dengan } \\
\text { Pada teknik pencahayaan } \\
\text { yang digunakan ini cukup } \\
\text { sederhana, derang } \\
\text { pencahayaan yang lebih } \\
\text { redup dan lebih terang } \\
\text { dalam menciptakan } \\
\text { kontras terang atau } \\
\text { gelap. }\end{array}$ \\
\hline \multicolumn{3}{|c|}{$\begin{array}{l}\text { Kearifan Lokal: Nilai-nilai memiliki kasih sayang pada sesama tanpa pandang } \\
\text { bulu }\end{array}$} \\
\hline $\begin{array}{l}\text { nilai dilandasi rasa kasih sayang } \\
\text { dan rela berkorban tampak } \\
\text { ketika Mak dan Natsir menolong } \\
\text { Hans yang tergeletak di jalan, }\end{array}$ & $\begin{array}{l}\text { Perilaku menolong } \\
\text { Hans yang pingsan di } \\
\text { Jalan. } \\
\text { Latar scene ini adalah } \\
\text { jembatan untuk } \\
\text { menuju ke pasar, yang } \\
\text { rencan awalnya mau } \\
\text { buat bunuh diri si } \\
\text { Hans (Orang Papua) } \\
\text { yang putus asa. }\end{array}$ & $\begin{array}{l}\text { Pengambilan gambar } \\
\text { medium shoot } \\
\text { Perempuan ini (Mak) } \\
\text { ibaratnya seorang ibu } \\
\text { yang penuh kasih sayang } \\
\text { menolong orang yang } \\
\text { sebetulnya bukan siapa } \\
\text { siapa baginya. } \\
\text { Teknik back light } \\
\text { ditempatkan } \\
\text { belakang subjek dan } \\
\text { digunakan } \\
\text { pencahayaan subjek dari } \\
\text { belakang }\end{array}$ \\
\hline
\end{tabular}

Sumber: Hasil Olahan Penulis 


\section{Peran perempuan sebagai pemimpin}

Tabel 3. Analisis Pada Temuan Kategori 2

\begin{tabular}{|c|c|c|}
\hline Gambar & Level realitas & $\begin{array}{c}\text { Level representasi pada } \\
\text { kearifan lokal }\end{array}$ \\
\hline \multicolumn{3}{|c|}{ Kearifan Lokal: Nilai-nilai kerja keras dan mandiri } \\
\hline $\begin{array}{l}\text { Hans mengiring } \\
\text { ketika Mak be } \\
\text { untuk kebutuha }\end{array}$ & 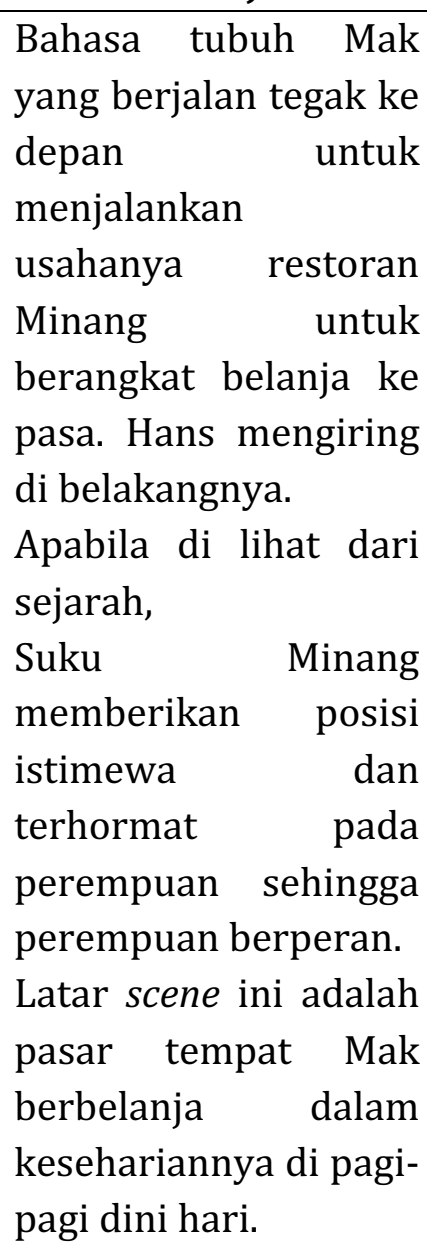 & $\begin{array}{l}\text { Pengambilan gambar } \\
\text { kearifan lokal yang } \\
\text { terlihat disini adalah kerja } \\
\text { keras dan mandiri } \\
\text { Teknik pencahayaan Fill } \\
\text { Light adalah cahaya } \\
\text { pengisi di bagian yang } \\
\text { berlawanan, sehingga } \\
\text { tampak lebih redup }\end{array}$ \\
\hline \multicolumn{3}{|c|}{ Kearifan Lokal: Nilai-nilai berpendirian kokoh dan memiliki idealisme } \\
\hline $\begin{array}{l}\text { Mak memandang dengan sorot } \\
\text { mata tajam ke Uda }\end{array}$ & 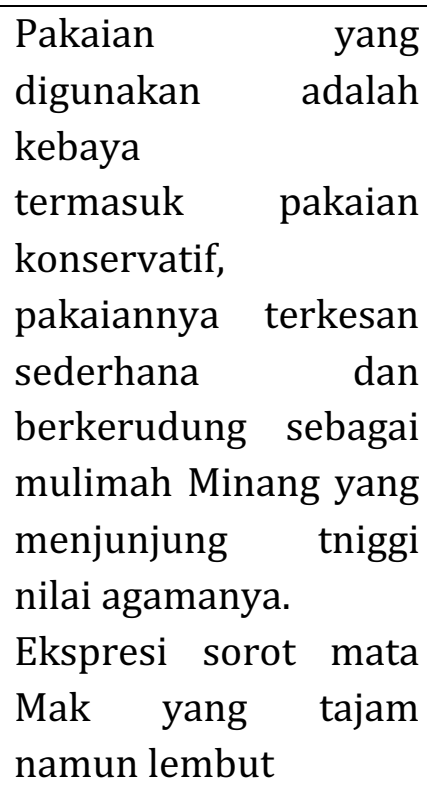 & $\begin{array}{l}\text { Pengambilan gambar } \\
\text { dengan close up. } \\
\text { Sedangkan dilihat dari } \\
\text { Karakter Mak adalah } \\
\text { wanita kuat dan kokoh } \\
\text { pendiriannya, dan } \\
\text { mempunyai idealisme. } \\
\text { Teknik pencahayaan Fill } \\
\text { Light adalah cahaya } \\
\text { pengisi di bagian yang } \\
\text { berlawanan, sehingga } \\
\text { tampak lebih redup }\end{array}$ \\
\hline
\end{tabular}




\begin{tabular}{|c|c|c|}
\hline & $\begin{array}{l}\text { Latar scene ini adalah } \\
\text { ruang tengah dekat } \\
\text { dapur Mak. }\end{array}$ & \\
\hline \multicolumn{3}{|c|}{$\begin{array}{c}\text { Kearifan Lokal: Nilai-nilai memiliki kekuatan dominasi dan kekuasaan sebagai } \\
\text { perempuan Minang }\end{array}$} \\
\hline $\begin{array}{l}\text { Mak dengan tegas memarahi } \\
\text { Hans pria asal Papua meminta } \\
\text { uang karena sudah menyemen } \\
\text { lantai, sebelumnya tidak ada } \\
\text { kesepakatan untuk memberikan } \\
\text { uang, hanya makanan. }\end{array}$ & $\begin{array}{l}\text { Pakaian Perempuan } \\
\text { tua atau Mak } \\
\text { berkerudung dan baju } \\
\text { krem bermotif bunga. } \\
\text { Ekspresi wajah marah, } \\
\text { perempuan tersebut } \\
\text { menunjuk seorang } \\
\text { laki-laki muda } \\
\text { disampingnya. Laki- } \\
\text { laki muda berkulit } \\
\text { gelap dengan rambut } \\
\text { dan kumis yang tidak } \\
\text { tertata rapi. } \\
\text { Latar scene ini adalah } \\
\text { di dalam rumah makan } \\
\text { Takana Juo. }\end{array}$ & $\begin{array}{l}\text { Pengambilan gambar } \\
\text { medium close up } \\
\text { merupakan teknik } \\
\text { kamera yang digunakan } \\
\text { pada gambar ini agar } \\
\text { ekspresi antara dua orang } \\
\text { tersebut } \\
\text { Dialog terjadi ketika Hans: } \\
\text { "ibu saya minta uang } \\
\text { lantai dapur sudah saya } \\
\text { semen tadi" kemudian } \\
\text { mak menjawab "kapan } \\
\text { saya janji kasih uang? lagi } \\
\text { pula uang untuk apa? } \\
\text { untuk makan? kamu kan } \\
\text { sudah saya kasih makan “. } \\
\text { Mendengar jawaban } \\
\text { tersebutlaki-laki itu mulai } \\
\text { emosi dan berkata "kuli } \\
\text { saja mereka kerja dapat } \\
\text { uang ibu, bukan makan } \\
\text { saja". Kemudian Mak } \\
\text { menjawab "tetapi saya } \\
\text { tidak janji mau kasih } \\
\text { kamu uang". Mak tidak } \\
\text { mau memberi uang dan } \\
\text { berkata "terserah! yang } \\
\text { penting kamu keluar dari } \\
\text { rumah makan saya sana } \\
\text { keluar!" lokal yang } \\
\text { Kearifan disini adalah } \\
\text { terlihat dan dominasi } \\
\text { ketegasan dan } \\
\text { perempuan }\end{array}$ \\
\hline
\end{tabular}




\begin{tabular}{|c|c|c|}
\hline \multicolumn{3}{|c|}{ Kearifan Lokal: Nilai-nilai memiliki percaya diri dan pantang menyerah } \\
\hline $\begin{array}{l}\text { Mak selalu menetapkan standar } \\
\text { rasa yang terbaik di warungnya }\end{array}$ & 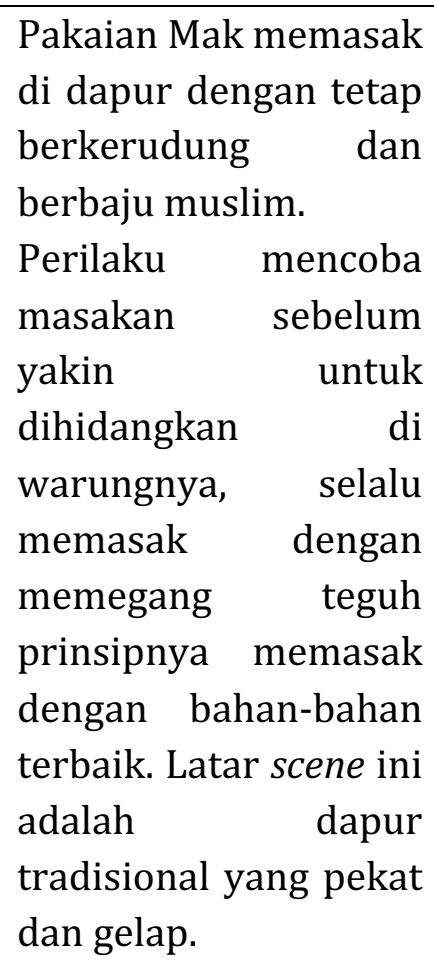 & $\begin{array}{l}\text { Pengambilan gambar } \\
\text { medium Long Shot, } \\
\text { kemudian kandungan } \\
\text { Nilai-nilai kearifan lokal } \\
\text { yang terlihat disini adalah } \\
\text { percaya diri dan pantang } \\
\text { menyerah. } \\
\text { Teknik pencahayaan Fill } \\
\text { Light adalah cahaya } \\
\text { pengisi di bagian yang } \\
\text { berlawanan, sehingga } \\
\text { tampak lebih redup }\end{array}$ \\
\hline \multicolumn{3}{|c|}{ Kearifan Lokal: Nilai-nilai berperilaku adil dan tidak membeda-bedakan suku } \\
\hline & $\begin{array}{l}\text { Perilaku Mak yang } \\
\text { mampu } \\
\text { memimpin saudara } \\
\text { sendiri dan juga orang } \\
\text { lain (Hans) yang orang } \\
\text { Papua untuk diberikan } \\
\text { tanggungjawab yang } \\
\text { sama secara adil. } \\
\text { Latar scene ini adalah } \\
\text { dapur tempat } \\
\text { memasak penuh uap } \\
\text { memasak. }\end{array}$ & $\begin{array}{l}\text { Pengambilan gambar } \\
\text { dengan Close Up. } \\
\text { Kearifan lokal yang } \\
\text { terlihat disini adalah } \\
\text { mampu berperilaku adil } \\
\text { walaupun salahsatunya } \\
\text { masih saudara, tidak } \\
\text { membeda-bedakan } \\
\text { walaupun Hans adalah } \\
\text { orang lain bukan satu } \\
\text { suku. } \\
\text { Teknik pencahayaan } \\
\text { (membantu mengurangi } \\
\text { bayang yang dihasilkan } \\
\text { oleh key light (sumber } \\
\text { cahaya utama) sehingga } \\
\text { gambar nampak lebih } \\
\text { natural. }\end{array}$ \\
\hline
\end{tabular}

Sumber: Hasil Olahan Penulis 


\section{Peran perempuan sebagai inspirator dan motivator}

Tabel 4. Analisis Pada Temuan Kategori 3

\begin{tabular}{|c|c|c|}
\hline Gambar dan dialog & Level realitas & $\begin{array}{l}\text { Level representasi pada } \\
\text { kearifan lokal }\end{array}$ \\
\hline \multicolumn{3}{|c|}{$\begin{array}{c}\text { Kearifan Lokal: Nilai-nilai memiliki kekuatan adil, selalu memotivasi dan } \\
\text { berbaur dengan sesama }\end{array}$} \\
\hline $\begin{array}{l}\text { Emak sangat bersemangat } \\
\text { mengajarkan Hans masak } \\
\text { rendang Padang }\end{array}$ & $\begin{array}{l}\text { Penampilan } \\
\text { Mak diperlihatkan } \\
\text { selalu menggunakan } \\
\text { penutup kepala } \\
\text { menunjukan } \\
\text { muslimah sebagai } \\
\text { orang Minang bahkan } \\
\text { saat sedang memasak } \\
\text { di dapur yang pengap } \\
\text { dan penuh asap dan } \\
\text { karena ada Hans yang } \\
\text { bukan mahramnya. } \\
\text { Mak bersemangat } \\
\text { mengajari Hans } \\
\text { tahapan memasak } \\
\text { masakan Minang. } \\
\text { Latar scene ini adalah } \\
\text { dapur Mak. }\end{array}$ & $\begin{array}{l}\text { Pengambilan gambar Close } \\
\text { Up, mampu } \\
\text { memperlihatkan ekspresi } \\
\text { wajah dengan jelas dan } \\
\text { gestur yang detil. } \\
\text { Kearifan lokal yang terlihat } \\
\text { disini Mak adalah sumber } \\
\text { inspirasi dn motivasi bagi } \\
\text { Hans untuk bersemangat } \\
\text { melanjtkan hidupnya } \\
\text { dengan belajar memasak } \\
\text { dari Mak. } \\
\text { Pencahayaan utama yang } \\
\text { diarahkan pada objek. }\end{array}$ \\
\hline \multicolumn{3}{|c|}{ Kearifan Lokal: Nilai-nilai bersedia berbaur dan bersatu } \\
\hline $\begin{array}{l}\text { Mak memutuskan Hans boleh di } \\
\text { warungnya,walaupun Uda tidak } \\
\text { setuju, Mak memberitahu Uda }\end{array}$ & $\begin{array}{l}\text { Perilaku Uni atau Mak } \\
\text { mampu menjadi } \\
\text { inspirator karena } \\
\text { mampu berbaur dan } \\
\text { juga mengupayakan } \\
\text { menyatunya Uda, dan } \\
\text { Natsir yang berasal } \\
\text { dari timur (Padang) } \\
\text { mampu berbaur akrab } \\
\text { dengan Hans yang } \\
\text { berasal dari Papua. }\end{array}$ & $\begin{array}{l}\text { Pengambilan gambar } \\
\text { dengan Close Up, mampu } \\
\text { memperlihatkan ekspresi } \\
\text { wajah dengan jelas dan } \\
\text { gestur yang detil. } \\
\text { Kearifan lokal yang terlihat } \\
\text { disini adalah adil } \\
\text { walaupun salahsatunya } \\
\text { masih saudara, bahkan } \\
\text { Hans justru orang lain. } \\
\text { Teknik pencahayaan } \\
\text { (membantu mengurangi } \\
\text { bayang yang dihasilkan }\end{array}$ \\
\hline
\end{tabular}




\begin{tabular}{|c|c|c|}
\hline $\begin{array}{l}\text { supaya mengikuti apa kemauan } \\
\text { Mak. }\end{array}$ & $\begin{array}{l}\text { Latar scene ini adalah } \\
\text { di depan rumah makan } \\
\text { Takana Juo. }\end{array}$ & $\begin{array}{l}\text { oleh key light (sumber } \\
\text { cahaya utama) sehingga } \\
\text { gambar nampak lebih } \\
\text { natural. }\end{array}$ \\
\hline \multicolumn{3}{|c|}{$\begin{array}{c}\text { Kearifan Lokal: Nilai-nilai memiliki kekuatan memotivasi dan memiliki } \\
\text { idealisme }\end{array}$} \\
\hline $\begin{array}{l}\text { Mak menegaskan bahwa dalam } \\
\text { menyajikan masakan harus } \\
\text { enak. }\end{array}$ & $\begin{array}{l}\text { Perilaku Uni atau Mak } \\
\text { mampu menjadi } \\
\text { inspirator, sangat kuat } \\
\text { pendirian dan harus } \\
\text { meyakinkan bahwa } \\
\text { masakan Padang yang } \\
\text { dia jual harus enak. }\end{array}$ & $\begin{array}{l}\text { Pengambilan gambar } \\
\text { dengan Close Up } \\
\text { Dialog antara mamak } \\
\text { dengan Uda yaitu: } \\
\text { "bagaimana orang akan } \\
\text { datang ke sini kalau } \\
\text { masakan kita tidak enak". } \\
\text { Disini Mamak sangat kuat } \\
\text { pendirian dan harus } \\
\text { meyakinkan bahwa } \\
\text { masakan Padang yang dia } \\
\text { jual harus enak. } \\
\text { Pencahayaan dari arah } \\
\text { belakang objek }\end{array}$ \\
\hline \multicolumn{3}{|c|}{ Kearifan Lokal: Nilai-nilai menjaga kerukunan } \\
\hline $\begin{array}{l}\text { Merekabertiga (Uda, Natsir, } \\
\text { Hans) bersatu memasak karena } \\
\text { Mak sakit. }\end{array}$ & $\begin{array}{l}\text { Menunjukkan Perilaku } \\
\text { bersatunya Uda yang } \\
\text { menyadari } \\
\text { kekeliruannya karena } \\
\text { telah keluar dari } \\
\text { rumah makan, untuk } \\
\text { kemudian membantu } \\
\text { Natsir dan Hans } \\
\text { memasak karena Mak } \\
\text { jatuh sakit. }\end{array}$ & $\begin{array}{l}\text { Pengambilan gambar } \\
\text { dengan Medium Long } \\
\text { Shoot. } \\
\text { Kearifan lokal yang terlihat } \\
\text { disini adalah rukun dan } \\
\text { bersatu. } \\
\text { Teknik pencahayaan Fill } \\
\text { Light adalah cahaya } \\
\text { pengisi di bagian yang } \\
\text { berlawanan, sehingga } \\
\text { tampak lebih redup }\end{array}$ \\
\hline
\end{tabular}

Sumber: Hasil Olahan Penulis

Pada level realitas menunjukkan representasi pada peran perempuan yang melaksanakan dwiperan yaitu memposisikan perempuan dalam kehidupan dua dunia, yaitu menempatkan peran domestik dan publik dalam posisi sama penting menghasilkan tiga peran yaitu: (1) Peran sebagai Ibu. Ibaratnya ibu adalah bangunan kehidupan dengan penopang perjalanannya yang memberikan sesuatu tanpa meminta imbalan dan harga. Apabila ada sifat yang mengutamakan orang lain, sifat tersebut ada pada ibu. Jika ada 
keikhlasan di dalam keikhlasan seorang ibu. (2) Peran sebagai pemimpin. Keberadaan peran perempuan sebagai pimpinan yang dalam hal ini diwakili oleh tokoh Mak yang memimpin rumah makan Takana Juo memiliki karakter yang pantang menyerah hidup di perantauan Jakarta. Perempuan itu pada dasarnya memiliki kemampuan mengerjakan banyak hal (multitasking) bahkan seluruhnya bisa dilakukan dengan konsentrasi yang sama. Perempuan ingin semua bisa selesai dengan hasil baik serta memahami masalah lebih prioritas agar solusi makin cepat. Perempuan juga mampu mengontrol emosinya. Peran sebagai inspirator dan motivator. Peran perempuan sebagai sumber inspirasi dan mampu memberikan keteladanan dalam keluarga. Biasanya perempuan yang menginspirasi orang lain dia pasti menjadikan dirinya bermanfaat untuk orag lain juga dan memiliki karakter yang kuat dan sekaligus bisa menginspirasi dirinya sendiri. Halhal yang melekat pada peran ini adalah perempuan akan mudah bangkit ketika menghadapi masalah, tidak mudah menyerah untuk selalu belajar, berupaya mengembangkan kemampuan yang dimiliki, selalu berusaha memberi manfaat untuk orang lain. Hal ini tercermin pada tokoh utama perempuan dalam film ini yaitu Mak.

Dari temuan penelitian pada ketiga peran perempuan yang ditemukan pada hasil analisis pada level realitas dan level representasi menunjukkan ciri kearifan lokal yang dimiliki pada budaya Minang di mana memiliki kekuatan dalam menyajikan masakan khas daerah tersebut sehingga terkandung banyak nilai nilai kekuatan diri yang khas antara lain: Nilai nilai integritas dalam mempertahankan Kuliner Budaya Minang; Nilai-nilai kasih sayang yang dimiliki dan bersedia berbagi; Nilai-nilai memiliki kasih sayang pada sesama tanpa pandang bulu; Nilai-nilai memiliki sifat kerja keras dan mandiri; Nilai-nilai berpendirian kokoh; Nilai-nilai memiliki kekuatan dominasi dan kekuasaan sebagai perempuan Minang; Nilai-nilai percaya diri dan pantang menyerah; Nilai-nilai berperilaku adil dan tidak membeda-bedakan suku; Nilai-nilai berkeadilan, dan berbaur dengan sesama; Nilai-nilai menjaga persatuan; Nilai-nilai memiliki kekuatan memotivasi dan memiliki idealisme; Nilai-nilai menjaga kerukunan

\section{Analisis pada Level ketiga yaitu ideologi}

Menunjuk pada semua elemen diorganisasikan dan dikategorikan dalam kode-kode ideologis, maka dalam kajian film Tabula Rasa ini terkandung ideologi Matrilineal. Dikarenakan peran perempuan sebagai mengangkat kuliner yaitu memopulerkan kuliner memperkuat identitas kuliner menjalankan peran domestik dan publik sehingga mereka diposisikan sebagai pemimpin keluarga yang penuh kasih sayang dan mandiri serta kuat. Perempuan pada ciri ideologis ini memiki kekuatan menjaga kekeluargaan, lentur, dan sebagai role model. Perempuan berusaha menciptakan suasana kekeluargaan dengan tujuan agar keluarga dan karyawan yang terlibat didalam aktivitas warung merasa selalu nyaman untuk diajak perempuan sebagai inspirator dan motivator yang mempertahankan masakan Minang.

Sistem matrilineal adalah suatu sistem yang mengatur kehidupan dan ketertiban masyarakatnya dalam jalinan kekerabatan garis ibu (Yustiarti, 2016, p. 1). Anak laki-laki 
atau perempuan dalam keluarga adalah bagian garis turunan yang di bawa darah ibu mereka. Seorang ayah dalam keluarga inti tidak dapat memasukkan anaknya ke dalam sukunya (yang terjadi di sistem patrilineal) yang dianut oleh mayoritas suku lainnya di Indonesia. Perempuan menempati sistem matrilineal ini memberikan ruang dan hak-hak bagi kaum perempuan. Perempuan memiliki akses yang besar masuk ke ruang publik karena perempuan minang memiliki properti yang memadai. Perempuanlah yang memegang dan mengelola harta benda bukan laki-laki. Perempuan pun bisa menjadi pemimpin.

Garis matrilineal di sini mengacu kepada satu sistem di mana adat telah menetapkan garis keturunan Ibu. Itu artinya, perempuan menjadi pemimpin berkebalikan dengan fakta yang menyebut bahwa pimpinan berada di pundak lelaki. Berbeda dengan budaya patrilineal yang merupakan garis keturunan ayah. Bukan hanya dari segi kepemimpinan, hal unik lain dari struktur matrilineal ini adalah semua hak adalah milik perempuan.

Dengan demikian film ini memiliki tujuan dalam menguatkan peran perempuan dalam mempertahankan kearifan lokal melalui performa kekuatan diri yang dimiliki. Penguraian kandungan makna dalam film tersebut menguatkan identitas dan posisi perempuan dalam Budaya Indonesia. Dalam hal ini media film tidak hanya sekedar hubungan pengirim pesan antara satu pihak ke pihak lainnya. Lebih dari itu semua media dilihat sebagaai produksi dan pertukaran makna. Titik tekannya pada bagaimana pesan berinteraksi dengan orang untuk memproduksi makna berkaitan dengan peran teks di dalam kebudayaan.

\section{SIMPULAN}

Dengan demikian dapat disimpulkan bahwa sesuai dengan pisau analisis semiotika John Fiske menghasilkan tiga peran perempuan yaitu peran ibu, peran pemimpin dan peran inspirator dan motivator. Dengan ketiga peran tersebut pada level realitas dan level representasi menunjukkan ciri kearifan lokal yang dimiliki pada budaya Minang di mana memiliki kekuatan dalam menyajikan masakan khas daerah tersebut sehingga terkandung banyak nilai nilai kekuatan diri yang berakar pada budaya antara lain: nilai nilai integritas dalam mempertahankan Kuliner Budaya Minang, nilai-nilai kasih sayang yang dimiliki dan berbagi, nilai memandang sesama tanpa pandang bulu, nilai-nilai memiliki kerja keras dan mandiri, nilai-nilai Nilai-nilai kokoh dalam pendirian dan idealisme, nilai-nilai kekuatan dominasi dan kekuasaan sebagai perempuan Minang, nilai-nilai percaya diri dan pantang, nilai-nilai berperilaku adil dan tidak membedabedakan suku, nilai-nilai berkeadilan, selalu memotivasi dan berbaur dengan sesama, nilai-nilai menjaga persatuan, nilai-nilai memiliki kekuatan memotivasi, dan nilai-nilai menjaga kerukunan. Secara keseluruhan penguraian kandungan makna dalam film Tabula Rasa ini menguatkan identitas dan posisi perempuan dalam Budaya Indonesia, terutama dalam hal ini adalah perempuan Minang dengan garis keturunan Matrilineal. 
Seorang perempuan Minang perantauan tetap menjalankan perannya sebagaimana semestinya dan mereka memandang budaya matrilineal adalah budaya yang positif dimanapun mereka berada. Diantara banyaknya Budaya Indonesia budaya dari Tanah Minang Kabau ini adalah salahsatu budaya Indonesia yang masih mengakar dan tertanam pada jiwa setiap masyarakatnya yang mampu bertahan dan mempertahankan nilai-nilai kebudayaannya.

\section{DAFTAR PUSTAKA}

Ahdiah, I. (2013). Peran-peran Perempuan dalam Masyarakat. Jurnal Academica, 05(02), 1085-1092. Diperoleh dari http://jurnal.untad.ac.id/jurnal/index.php/academica/article/view/2247/1450

Budiono, T., Herieningsih, S.W., \& Lukmantoro, T. (2013). Pemaknaan Tren Fashion Berjilbab Ala Hijabers Oleh Wanita Muslimah Berjilbab. Interaksi Online, 1(3). Diperoleh dari https://ejournal3.undip.ac.id/index.php/interaksionline/article/view/2962

Bungin, B. (2007). Penelitian Kualitatif. Putra Grafika

Fajarini, U. (2014). Peranan Kearifan Lokal dalam Pendidikan karakter. Sosio-Didaktika: Social Science Education Journal, 1(2), 123-130. https://doi.org/10.15408/sd.v1i2.1225

Hubeis, A. V. S. (2010). Pemberdayaan Perempuan dari Masa ke Masa. IPB Press.

Istiawati, N. F. (2016). Pendidikan Karakter Berbasis Nilai-Nilai Kearifan Lokal Adat Ammatoa Dalam Menumbuhkan Karakter Konservasi. Cendekia: Jurnal Pendidikan Dan Pembelajaran 10(1), 1-18. https://doi.org/10.30957/cendekia.v10i1.78

Konsulat Jendral Republik Indonesia: Frankfurt. (2016). Sekilas Tentang Indonesia. https://www.indonesia-frankfurt.de/pendidikan-budaya/sekilas-tentangbudaya-indonesia/

Lukitasari, R. (2019). Penguatan Reputasi Masakan Padang: Simbol Promosi Pariwisata Gastronomi dalam Film Tabula Rasa. Jurnal Master Pariwisata (JUMPA), 6(1), 124. https://doi.org/10.24843/JUMPA.2019.v06.i01.p01

Nesi, A., Rahardi, RK., \& Pranowo. (2019). Nilai-nilai Kearifan Lokal dalam Tradisi Lisan Takanab: Kajian Ekolinguistik. Jurnal Pendidikan dan Kebudayaan Missio. 11(1), 71-90.

Diperoleh

dari

http://unikastpaulus.ac.id/jurnal/index.php/jpkm/article/view/138/110

Pah, T., \& Darmastuti, R. (2019). Analisis Semiotika John Fiske Dalam Tayangan Lentera Indonesia Episode Membina Potensi Para Penerus Bangsa Di Kepulauan Sula. Communicare : Journal of Communication Studies, 6(1), 1 - 22. https://doi.org/10.37535/101006120191 
Pratista, H. (2008). Memahami Film. Yogyakarta: Homerian Pustaka.

Pratami, S. (2015). "Multikulturalisme Cita Rasa Masakan dalam Film Tabula Rasa", Fakultas Ilmu Komunikasi, Universitas Mercu Buana

Suryani, Ita. (2014). Peran Media Film Sebagai Media Kampanye Lingkungan Hidup: Studi Kasus Pada Film Animasi 3D India "Delhi Safari”. Jurnal Ilmu Komunikasi Vol 2(2), 79-90. Diperoleh dari https://Journal.Budiluhur.Ac.Id/Index.Php/Avantgarde/Article/Viewfile/10/28

Vera, N. (2014). Semiotika dalam Riset Komunikasi. Ghalia Indonesia.

Wibowo, I.S.W. (2013). Semiotika Komunikasi, Aplikasi Praktis bagi Penelitian dan Skripsi Komunikasi (2nd ed.). Mitra Wacana Media.

Yustiarti, B. (2016, Agustus 31). Balutan Sistem Kekerabatan matrilineal. Kompasiana. https://www.kompasiana.com/bekti/57c63c83169773f93eadbec7/balutansistem-kekerabatan-matrilineal. 